УДК 340.134

DOI https://doi.org/10.51989/NUL.2021.4.39

\title{
ВПЛИВ ЗАПРОВАДЖЕННЯ ПРАВОВОГО РЕЖИМУ НАДЗВИЧАЙНИХ СИТУАЦІЙ НА ЗДІЙСНЕННЯ ПРАВОСУДДЯ
}

\author{
Сатаренко Віталій Володимирович,
}

командир Полку патрульної служби поліції особливого призначення «Київ»

Головного управління Національної поліції в місті Києві

У статті розглянуто практичний досвід здійснення правосуддя в Україні в період дії режиму надзвичайних ситуацій, а також проаналізовані відповідні нормативні акти щодо піднятого питання. Методологічну основу дослідження склали методи, що дозволили отримати обґрунтовані та логічно вивірені висновки, а саме гносеологічний метод, що використовувався для опрацювання вітчизняних і міжнародних нормативно-правових актів із приводу питання обмеження прав та свобод під час запровадження режиму надзвичайних ситуацій; герменевтичний - у процесі дослідження наукових позицій різних авторів щодо юридичної природи правового режиму; метод узагальнення, використання якого допомогло виявили особливості здійснення правосуддя в період дії режиму надзвичайного стану. У статті описано основні риси функціонування судової системи в разі введення надзвичайних ситуацій. У результаті проведеного дослідження було зроблено такі висновки: по-перше, правовий режим є специфічним явищем, що з нормативної точки зору за допомогою певного інструментарію впливає на повсякденне життя суспільства. У залежності від предмета правового регулювання та галузевої направленості виділяють такий вид правового режиму, як режим надзвичайної ситуації. По-друге, актуальним постає питання щодо особливостей реалізації прав і свобод людини та громадянина у зв'язку із запровадженням режиму надзвичайної ситуації. Як зазначено в низці міжнародних документів, обмеження конституційних прав людини під час запровадження такого режиму можливе лише щодо деяких прав. По-третє, наріжним каменем функціонування принципу верховенства права $\epsilon$ питання здійснення ефективного правосуддя в період дії режиму надзвичайних ситуацій, особливо щодо кримінального провадження. У свою чергу це слугує передумовою для запровадження нової методики проведення судових засідань у період обмежень. По-четверте, виходячи із сучасних реалій та процесу судової реформи, Україна готова до здійснення належного функціонування судової влади в режимі надзвичайних ситуацій, що підтверджено наявністю налагодженої нормативної і методологічної бази.

Ключові слова: правосуддя, правовий режим, надзвичайна ситуація, обмеження прав та свобод людини, верховенство права.

\section{Satarenko Vitalii. The impact of the introduction of the legal regime of emergencies on the administration of justice}

The aim of the article is to analyze the existing regulations on the administration of justice during the emergency regime and study the current practical experience of Ukraine on the issue. The methodological basis of the study were methods that allowed to obtain reasonable and logically verified conclusions, namely: epistemological method used in the development of domestic and international regulations on the issue of restriction of rights and freedoms during the introduction of emergency situations; hermeneutic - in the process of studying the scientific positions of various authors on the legal nature of the legal regime; the method of generalization, the use of which helped to identify the features of the administration of justice during the state of emergency. The article describes the main features of the judicial system in the introduction of emergencies. According to the study were made such conclusions as: first, the legal regime is a specific phenomenon that from a normative point of view with the help of certain tools affects the daily life of society. Depending on the subject of legal regulation and sectoral orientation, there is such a type of legal regime as the state of emergency. Secondly, the question of the peculiarities of the realization of human and civil rights and freedoms in connection with the introduction of the state of emergency is relevant. As stated in a number of international instruments, restrictions on constitutional human rights during the introduction of such a regime are possible only in respect of certain rights. Third, the cornerstone of the rule of law is 
the administration of effective justice during emergencies, especially in criminal proceedings. In turn, this is a prerequisite for the introduction of a new method of conducting court hearings in the period of restrictions. Fourth, based on modern realities and the process of judicial reform, Ukraine is ready for the proper functioning of the judiciary in emergencies, which is confirmed by the existence of a well-established regulatory and methodological framework.

Key words: justice, legal regime, state of emergency, restriction of human rights and freedoms, rule of law.

Актуальність теми. Питання реалізації права особи на неупереджений та справедливий суд завжди набували своєї актуальності, як за часів стародавнього Риму, так і в нинішніх реаліях розвитку суспільства. Однак останні роки людство перебуває як у полоні епідемії, що позначилося на можливих обмеженнях реалізації конституційних прав і свобод людей, так і стихійних лих та військових заворушень, що також впливають на втілення зазначеного. У свою чергу окреслене відбивається на можливості судового захисту, що й зумовило звернення до піднятого питання.

Мета статті полягає в аналізі наявних нормативних актів щодо питання реалізації правосуддя в період дії режиму надзвичайних ситуацій та дослідженні сучасного практичного досвіду України щодо даного питання. У свою чергу окреслена автором мета може бути досягнута шляхом надання відповіді на такі завдання: визначити, що варто розуміти під дефініцією «правовий режим» та як це корелюється з надзвичайним станом; розкрити питання щодо можливості обмеження конституційних прав і свобод людини під час запровадження режиму надзвичайної ситуації; виявити вплив запровадження режиму надзвичайної ситуації на здійснення правосуддя; надати відповідь, чи готова Україна до здійснення правосуддя в період запровадження режиму надзвичайної ситуації.

Задля досягнення окресленої мети та завдань було використано низку методів, зокрема таких, як: гносеологічний під час опрацювання вітчизняних і міжнародних нормативно-правових актів із приводу питання обмеження прав та свобод під час запровадження режиму надзвичайної ситуації; герменевтичний - у процесі дослідження наукових позицій різних авторів щодо юридичної природи правового режиму, узагальнення, використання якого допомогло виявили особливості здійснення правосуддя в період дії режиму надзвичайного стану.
Теоретичну основу нашого дослідження, зокрема щодо питання юридичної природи правового режиму, склали напрацювання Г.С. Бєляєвої, Е.Ф. Шамсумова, С.К. Могил, Р.І. Мельника та Т.П. Чубко. Також у цьому процесі були використані напрацювання Л. Чернявської щодо питання діяльності вітчизняних судів під час дії надзвичайних ситуацій, В.В. Лемака щодо особливостей обмеження прав та свобод людини в Україні, звітні дані ОБСЄ, які розкривають питання міжнародних аспектів здійснення правосуддя під час запровадження режиму надзвичайних ситуацій.

Викладення основного матеріалу. Правовий режим - складне, багатогранне правове явище, що полягає в специфічному поєднанні прийомів і засобів регулювання, котре має своє відповідне нормативне підґрунтя та належну групу суспільних відносин [1, с. 126], що впливає на безпосереднє життя людей. Наразі в юридичній літературі наявний плюралізм наукових поглядів щодо визначення поняття правого режиму, тому здійснимо розгляд деяких із них. На думку Г.С. Бєляєвої, «правовий режим - це особливий нормативний порядок регулювання на основі установлених і забезпечених державою правових засобів, спрямований на створення умов для задоволення інтересів суб'єктів права, який виражається у специфіці способів і гарантій їх реалізації і заснований на дії спільних принципів, що приводять усі його елементи у впорядковану систему» [2, с. 30]. Натомість Е.Ф. Шамсумова пропонує розуміти окреслену категорію у двох значеннях широкому і вузькому. Отже, розглядаючи перший з них, авторка вважає, що під поняттям правового режиму варто розуміти «особливий порядок законодавчого врегулювання діяльності, дій або поведінки фізичних і юридичних осіб у різних сферах суспільних відносин або на певних об'єктах, що включає встановлення 
механізму забезпечення фактичної реалізації системи дозволів, стимулів, нормативів, гарантій, заборон, обмежень, зобов'язань, а також їх компетентне виконання і застосування заходів примусу і притягнення винних до відповідальності». При цьому у вузькому значенні науковець надає таке визначення цього терміна: «закріплене в нормах права особливе поєднання юридичного інструментарію (юридичних засобів), що характеризується наявністю особливих умов, конкретністю (визначеністю) суспільних відносин, станом відношення до певного об'єкта і переслідує корисну для суспільства і держави мету» [3, с. 6]. Із викладеного випливає, що спільними моментами або, краще сказати, елементами для будь-якого із зазначених визначень $\epsilon$ : наявність відповідного суб'єкта (фізична та/або юридична особа); об'єкта (сфера зацікавленості суб'єкта), врегульована на законодавчому рівні діяльність або поведінка суб'єкта щодо досягнення об'єкта, що виражається в наявності відповідного застосовуваного інструментарію (засоби, способи, прийоми тощо).

Отже, вагомим елементом правового режиму $\epsilon$ його суб'єктна складова частина, причому як та, що його запроваджує шляхом видання відповідних нормативноправових актів, так і та, що його безпосередньо реалізує. При цьому, на наше переконання, одним з актуальних питань діяльності суб'єкта щодо можливості реалізації своїх прав, свобод та юридичних обов'язків постає саме в запровадженні з боку держави відповідного правового режиму.

Як зазначає С.К. Могил, у сучасній юридичній літературі одним із критеріїв диференціації правового режиму $\epsilon$ саме галузевий підхід. При цьому багато спеціальних правових режимів виходять за межі як однієї галузі права, так і міжгалузевого регулювання. Прикладом автор наводить правовий режим надзвичайного стану, що, на його переконання, навряд чи може бути обмежений двома галузями права - конституційного й адміністративного. Як влучно зазначає науковець, наявність розходження в нормативно-правовому регулюванні у звичайних умовах і в екстремальних ситуаціях дає підстави для виділення правового режиму надзвичайного стану [4, с. 9].

Виходячи із зазначеного, на нашу думку, доволі актуальним постає питання щодо проблематики реалізації права на правосуддя в контексті запровадження режиму надзвичайного стану, що обмежує та унеможливлює повноцінне втілення прав і свобод людини. Притому особливої актуальності цьому завдає як сучасний політико-територіальний стан України, так і епідемічна ситуація, в якій наша держава перебуває майже півтора року.

Відповідно до ст. 31 Закону України «Про правовий режим надзвичайного стану» правосуддя на території, де введено надзвичайний стан, здійснюється лише судами, створеними відповідно до Конституції України. Введення будь-яких скорочених або прискорених форм судочинства забороняється [5].

Звертаючи свою увагу до міжнародного аспекту врегулювання реалізації правосуддя в режимі надзвичайних ситуацій, варто наголосити, що Гельсінський заключний акт 1975 р. зобов'язує державучасниць ОБСЄ «поважати основоположні права та свободи людини», а також «сприяти і заохочувати ефективну реалізацію громадянських, політичних, економічних, соціальних, культурних та інших прав і свобод, що випливають з невід'ємної людської гідності». У ст. 7 зазначеного акта вказано й на те, що держави-учасниці повинні «виконувати свої зобов'язання, викладені в міжнародних деклараціях та угодах у цій сфері, включаючи, зокрема, Міжнародні пакти про права людини, які можуть мати для них обов'язкову силу» [6]. У звітних документах ОБСЄ наголошується на тому, що дотримання принципу верховенства права, «що базується на повазі до міжнародно визнаних прав людини, включно з правом на справедливий судовий розгляд, правом на ефективний правовий захист та правом на захист від свавільного арешту чи затримання», набуває особливої актуальності саме під час кризи та запровадження режиму надзвичайної ситуації. Саме забезпечення незалежності діяльності судової гілки влади неодноразово визнавалося передумовою верховенства права та фундаментальною гарантією справедливого судового розгляду [7, с. 8]. 
3 огляду на вказане цілком слушним видається позиція суддів Конституційного суду України, які у своєму рішенні від 1 червня 2016 року № 2-рп/2016 (абзац 3 підпункту 2.1 пункту 2) наголошують на тому, що «обмеження щодо реалізації конституційних прав і свобод не можуть бути свавільними та несправедливими, вони мають установлюватися виключно Конституцією і законами України, переслідувати легітимну мету, бути зумовленими суспільною необхідністю досягнення цієї мети, пропорційними та обґрунтованим, у разі обмеження конституційного права або свободи законодавець зобов'язаний запровадити таке правове регулювання, яке дасть можливість оптимально досягти легітимної мети з мінімальним втручанням у реалізацію цього права або свободи і не порушувати сутнісний зміст такого права» [8].

В окремій думці судді Конституційного суду В.В. Лемака зазначено, що «державне втручання щодо прав і свобод людини, яке стосується не окремих індивідів, а переважної більшості суспільства, не може бути здійснене державою без запровадження особливого правового режиму, передбаченого Конституцією України» [9].

Ураховуючи сучасні особливості перебування всього людства в епідемічному надзвичайному режимі, спричиненому розповсюдженням нового виду коронавірусу, питання щодо забезпечення поваги до принципу верховенства права не може відходити на другий план. Як зазначають представники ОБСЄ, посилання на стан надзвичайної ситуації «не може використовуватися для підриву демократичного конституційного ладу, а також не має бути спрямоване на знищення міжнародно визнаних прав людини та основних свобод», а «фактичне запровадження або продовження надзвичайного стану, що не відповідає положенням закону, $\epsilon$ неприпустимим» [7, с. 8]. На підтвердження цього доречним буде згадати положення документу Московської наради 1991 р., в якому зазначено, що держави-учасниці «намагатимуться забезпечити, щоб юридичні гарантії, необхідні для підтримання верховенства права, залишались чинними під час надзвичайного стану» [10].

Однак попри зазначене, в міжнародних актах, зокрема в ст. 4 Міжнародного пакту про громадянські й політичні права [11] та ст. 15 Європейської конвенції з прав людини [12], передбачається, що задля стабілізації суспільної ситуації державі можливо тимчасово обмежувати певні права в період дії надзвичайної ситуації. При цьому наголошується, що існує низка прав, що не підлягають будь-якому обмеженню. До них, зокрема, відносять: право на захист від катувань та жорстокого поводження, а також елементи права на справедливий суд, такі як презумпція невинуватості, а також права, необхідні для забезпечення захисту прав, що не можуть бути обмежені, зокрема право на ефективний засіб правового захисту. Однак варто пам'ятати, що навіть тоді, коли звуження прав не передбачається, екстрені заходи, що обмежують основні свободи та права людини, повинні відповідати вимогам, передбаченим міжнародними документами, а також бути передбачені у відповідному національному законодавчому акті й відображати принципи пропорційності та недискримінації.

Під час запровадження надзвичайного стану держави-учасниці ОБСЄ взяли на себе зобов'язання «переконатися, аби юридичні гарантії, необхідні для підтримання верховенства права, залишались в силі» та «забезпечити у своєму законодавстві контроль за правилами, пов'язаними 3 надзвичайним станом, а також виконанням відповідних нормативних актів». При цьому, як зазначає Управління Верховного комісара з прав людини, паралельно має існувати «цілеспрямований судовий нагляд за надзвичайними заходами або надзвичайним станом, аби забезпечити їхню відповідність обмеженням». Крім того, «надзвичайні заходи, включно з обмеженням або призупиненням певних прав, підлягають періодичному та незалежному перегляду законодавцем».

Як зазначається в заяві Європейської комісії з питань ефективності правосуддя, ключові стандарти, що лежать в основі функціонування судів, повинні продовжувати діяти навіть у період дії режиму надзвичайних ситуаціях. Особливо це стосується кримінальних справ, коли особливої загрози зазнають такі правові категорії, як: принципи презумпції невинуватості; 
право на публічне слухання та захист; рівність сторін; право на законне представництво; на вивчення доказів та заслуховування свідків інших сторін; а також право на надання перекладача у разі потреби [7, с. 8]. Наприклад, у ст. 9 Міжнародного пакту про громадянські й політичні права [11] та ст. 5 Європейської конвенції з прав людини [12] передбачається, що під час запровадження режиму надзвичайних ситуацій правосуддя має відбуватися протягом розумного строку та з наданням різних гарантій, включаючи перевірку законності затримання компетентним судом. Також у ст. 9 зазначеного Пакту наголошується на тому, що «кожна заарештована або затримана за кримінальним обвинуваченням особа в терміновому порядку доставляється до судді чи до іншої службової особи, якій належить за законом право здійснювати судову владу» [11].

Варто зазначити, що наша держава в повній мірі реалізує зазначені міжнародні положення. Наприклад, можемо навести окрему думку судді Конституційного суду України В.В. Лемака, де зазначено: «навіть виправданість і серйозність мети, яка полягає в захисті життя і здоров'я людей, для досягнення якої здійснюються обмеження в реалізації конституційних прав людини, не означає, що такі обмеження можуть бути здійснені свавільно та бути несумісними з фундаментальними конституційними цінностями верховенства права, демократії, захисту прав людини. Під час найважчих випробувань нації Конституція України діє таким же чином, як у звичайний період. Однак у складні часи з Основного Закону випливають додаткові позитивні обов'язки держави, які покликані захистити людину і суспільство від загроз» [9].

Якщо більш глибше звертатися до сучасних реалій реалізації вітчизняного правосуддя в режимі надзвичайних ситуацій, то, як влучно зазначає Л. Чернявська, готовність судів до безперервної роботи під час такого режиму посідає важливе місце в діяльності Проекту підтримки судової реформи, що у свою чергу зумовлено тривалим продовженням війни на сході України, спричиненою військовими діями соціально-економічною кризою, політичною нестабільністю в кра- їні [13], а також зміною повсякденного життя людства через розповсюдження коронавірусу.

у зв'язку із зазначеним актуальним стало запровадження в Україні відповідних нормативно-правових документів, які би врегульовували діяльність представників судової влади під час надзвичайних ситуацій - Типовий план забезпечення безперервної діяльності суду та Методичні рекомендації щодо безпеки в надзвичайних ситуаціях (брошури), затверджені наказом ДСА України від 29 січня 2019 р. № 93.

Як зазначено в цих актах, План забезпечення безперервної діяльності суду це процес планування дій на випадок надзвичайної ситуації, який надає можливість продовжувати виконання своїх основних функцій у випадку порушення звичайного режиму роботи суду. Кожен працівник суду повинен бути готовим до дій у випадку виникнення надзвичайної ситуації під час перебування на роботі. Важливим аспектом цієї відповідальності $\epsilon$ розуміння того, які саме дії мають відбуватись під час порушення звичайного режиму роботи суду. До структурних елементів зазначеного Плану відносять забезпечення безперервної діяльності судової гілки влади в разі виникнення будь-яких небезпечних ситуацій як типовий документ, який може бути адаптований до різних видів порушення звичайного режиму роботи, а також плану щодо забезпечення безперервної діяльності у випадку епідемії [14].

Підсумовуючи вищезазначене, можемо дійти висновків, що:

По-перше, правовий режим $є$ специфічним явищем, що з нормативної точки зору за допомогою певного інструментарію впливає на повсякденне життя суспільства. У залежності від предмета правового регулювання та галузевої направленості виділяють такий вид правового режиму, як режим надзвичайної ситуації.

По-друге, актуальним постає питання щодо особливостей реалізації прав та свобод людини та громадянина у зв'язку із запровадженням режиму надзвичайної ситуації. Як зазначено в низці міжнародних документів, обмеження конституційних прав людини під час запровадження 
такого режиму можливе лише щодо деяких прав.

По-третє, «наріжним каменем» функціонування принципу верховенства права $\epsilon$ питання здійснення ефективного правосуддя в період дії режиму надзвичайних ситуацій, особливо щодо кримінального провадження. У свою чергу це слугує передумовою для запровадження нової методики проведення судових засідань у період обмежень.

По-четверте, виходячи із сучасних реалій та процесу судової реформи, Україна готова до здійснення належного функціонування судової влади в режимі надзвичайних ситуацій, що підтверджено наявністю налагодженої нормативної та методологічної бази.

\section{ЛITEPATУРA:}

1. Окрема думка судді Конституційного Суду України Лемака В.В. стосовно Рішення Конституційного Суду України у справі за конституційним поданням Верховного Суду щодо відповідності Конституції України (конституційності) окремих положень постанови Кабінету Міністрів України «Про встановлення карантину з метою запобігання поширенню на території України гострої респіраторної хвороби COVID-19, спричиненої коронавірусом SARS-Co V-2, та етапів послаблення протиепідемічних заходів», положень частин першої, третьої статті 29 Закону України «Про Державний бюджет України на 2020 рік», абзацу дев'ятого пункту 2 розділу 11 «Прикінцеві положення» Закону України «Про внесення змін до Закону України «Про Державний бюджет України на 2020 рік» від 28 серпня 2020 року № 10-р/2020.

2. Особливості функціонування судів в умовах пандемії COVID-19. Базовий посібник ОБСЄ, 2020. 58 с.

3. Мельник P.I, Чубко Т.П. Проблеми обмеження прав і свобод людини в умовах дії спеціального правового режиму. Вісник Луганського державного університету внутрішніх справ імені Е.О. Дідоренка. 2016. № 1. С. 125-134.

4. Могил С.К. Сучасна держава в екстремальних ситуаціях: нормативи, органи, функції : автореф. дис. ... канд. юрид. наук. Одеса, 2003. 15 с.

5. Закон України «Про правовий режим надзвичайного стану» від 16 березня 2000 р. № 1550-III. Відомості Верховної Ради України. 2000. № 23. Ст. 176.

6. Беляева Г.С. Понятие правового режима в теории права: основные подходы. Вестник Саратовской государственной юридической академии. 2012. № 85. С. 26-31.

7. Типовий план забезпечення безперервної діяльності суду, затверджений Наказом Державної судової адміністрації України 29.01.2019 р. № 93. URL: https://dsa.court.gov.ua/ userfiles/media/!/Dod_1_N_93.pdf

8. Шамсумова Э.Ф. Правовые режимы: теоретический аспект : автореф. дис. ... канд. юрид. наук. Екатеринбург, 2001. 24 с.

9. Конвенція про захист прав людини і основоположних свобод : Конвенцію ратифіковано Законом № 475/97-ВР від 17.07.97 p. URL: https://zakon.rada.gov.ua/laws/show/995_004\#Text

10. Заключительный акт Совещания по безопасности и сотрудничеству в Европе. Хельсинки, 1 августа 1975 г. Сборник действующих договоров, соглашений и конвенций, заключенных СССР с иностранными государствами. Москва, 1977. Вып. XXXI. С. 544-589. URL: https://zakon.rada.gov.ua/laws/show/994_055\#Text

11. Міжнародний пакт про громадянські і політичні права (Міжнародний пакт ратифіковано Указом Президії Верховної Ради Української РСР № 2148-VIII (2148-08) від 19.10.1973 р. URL: https://zakon.rada.gov.ua/laws/show/ 995_043\#Text

12. Рішення Конституційного суду України у справі за конституційним поданням Уповноваженого Верховної Ради України з прав людини щодо відповідності Конституції України (конституційності) положення третього речення частини першої статті 13 Закону України «Про психіатричну допомогу» (справа про судовий контроль за госпіталізацією недієздатних осіб до психіатричного закладу) від 1 червня 2016 р. № 2-рп/2016.

13. Чернявська Л. Готовність до надзвичайних ситуацій та забезпечення безперервної роботи суду. Юридична газета. 2020. URL: https://yur-gazeta.com/dumka-eksperta/gotovnistdo-nadzvichaynih-situaciy-ta-zabezpechennya-bezperervnoyi-roboti-sudu-.html

14. Конференція з питань безпеки та співробітництва в Європі (КБСЄ), Документ Московської зустрічі Конференції з людського виміру КБСЕ, Москва, 3 жовтня 1991 року. 